confirmed. The apparent atomic weight of antimony increases with the concentration of the solution from which it is deposited. Methods for determining the atomic weights of the rare earths are discussed by $\mathrm{W}$. Wild ${ }^{1}$, who compares the volumetric and gravimetric processes. Rudorf ${ }^{2}$ has investigated the atomic weight of radium as deduced from regularities between the spectral lines, and favors the preliminary acceptance of $\mathrm{Ra}=225$. There are also memoirs on the general subject of the spectral regularities by Runge ${ }^{3}$ and by Watts. ${ }^{4}$ Wetherel1 ${ }^{5}$ has studied the relations between the atomic weights, and sought to explain their anomalies. On the vexed question of the standards there is another defense of the hydrogen unit by Erdmann, ${ }^{8}$ and the same chemist ${ }^{7}$ has proposed a table of rounded-off values for ordinary use. The international table for 1905 appeared in the January number of this Journal.

\title{
THE ELECTRICAL CONDUCTIVITY OF LIQUID AMPIONIA SOLUTIONS, II.
}

By Edward C. Franklin aNd Charles A. KRaUs,

Received Jatiuary 5, 1905 .

IN our earlier investigations on the electrical conductivity of liquid ammonia solutions ${ }^{8}$ attention was given especially to the determination of the maximum molecular conductivity of a number of salts in solution in this solvent at its boiling point, $-33^{\circ}$. As a consequence of the direction taken by this work measurements were made only on dilute solutions. The cell used was made for this special purpose and was not adapted to measurements on good conducting solutions. We were unable therefore, without reconstructing this essential part of the apparatus, to extend our measurements to concentrated solutions.

In our preliminary qualitative work we had found that many substances which are insoluble in water, or which, although soluble, form solutions which are non-conducting, dissolve in am-

1 Zischr. anorg. Chem., 38, I9I.

2 Ztschr. phys. Chem., 50, 100.

3 Ztschr. Elektrochem., 10, IIg.

+ Phil. Mag., Ser. 8, p. 279.

5 Chem. News, 90, 260, $27 \mathrm{I}$.

6 Chem. Ztg., 28, 679.

T Ztschr. angew. Chem., 38, 1397.

8 Am, Chem.J., 23, 277 (5900). 
monia to form conducting solutions. An extension of our earlier measurements to more concentrated solutions and the study of a wider range of solutes was accordingly made the subject of the present investigation. The program laid out for the work was interrupted and we have since allowed several years to elapse in the expectation of being able to continue it. However, as we shall not be able to take up the work again in the near future we deem it worth while to publish the results thus far obtained.

APPARATLTS.

The general form of the apparatus and the method of purifying the solvent and making up the solutions were in all essential respects the same as those used in our earlier investigations, for which reason it is unnecessary to repeat a description here. We may mention, however, the substitution of a solid nickel valve for the stop-cock $P$ in Fig. $2^{1}$ of our earlier paper, the use of several cells varying widely in resistance capacity, and a variation in the procedure for making up the more concentrated solutions and introducing them into the conductivity cell. It was hoped that the nickel valve would enable us to transfer the solvent from the condensing receptacle to the conductivity cell without contamination. In this hope we were disappointed, for, while it was easy to obtain ammonia in the condensing vessel with a specific conductivity as low as o.oI $\times 10^{-5}$, it was found that the conductivity of the solvent in the conductivity cell varied between even wider limits than it did when a glass stop-cock was used. For this reason measurenents were not carried to as high dilutions as was desired and the conductivity values given for the highest dilutions may be in error to the possible extent of several per cent. It should be remarked, however, that in no case in which the solvent was tested before and after making a series of measurements did the specific conductivity of the liquid exceed $0.3 \times 10^{-6}$.

In order to avoid the tedious process of making up the more concentrated solutions in the cell direct these were made in an accessory receptacle and transferred to the measuring cell through tubes sealed glass to glass. The transfers were made by means of compressed air.

THE SOLVENT.

In view of the fact that the value for the specific conductivity 1 Loc cit. p. $27 \%$. 
of pure ammonia as generally accepted $d^{1}$ is much higher than that given in our previous paper ${ }^{2}$ it may be well to emphasize here the results there given. We pointed out that ammonia with a specific conductivity below $0.01 \times 10^{-6}$ was easily obtained, but no attempt was made to determine the exact value for the reason that proper measuring instruments for the purpose were not at our disposal. Our measurements were made by the method of Kohlrausch with bridge and telephone in a cell with a resistance capacity of $0.05 \mathrm{o}$. With a resistance of $40,000 \mathrm{ohms}$ in the right arm of the bridge and the cell containing the liquid in the other, the position of the minimum, which became very indistinct at the highest resistances, could be located to within a few millimeters of its true position up to $980 \mathrm{~mm}$. on the bridge. In a number of experiments the minimum, while distinctly above $980 \mathrm{~mm}$. , could not be located. The specific conductivity of the liquid calculated from a setting at $980 \mathrm{~mm}$. is $0.025 \mathrm{x} \mathrm{IO}^{-6}$.

Since publishing our earlier results we have obtained ammonia in the condensing receptacle of our apparatus with a resistance so high that a difference of potential of I Io volts between electrodes having a cell constant of 0.050 failed to send sufficient current through the cell to produce an observable deflection on a Weston milliameter. A deflection of one-tenth of the smallest scale division, which is very easily observable, corresponds to a current of $0.0000 \mathrm{I}$ ampere, and gives a specific conductivity for the solvent as follows: $\kappa=\mathrm{Ci} / \pi=0.050 \times 0.0000 \mathrm{I} / \mathrm{I} \mathrm{IO}=0.005 \mathrm{x}$ $10^{-6}$, where $\kappa$ is the specific conductivity of the liquid and $\pi$ is the difference of potential between the electrodes. This experiment was repeated a number of times on different specimens of the solvent, so there can be no doubt that the value given above constitutes an upper limit above which the specific conductivity of pure ammonia does not lie.

That the specific conductivity of pure ammonia is very low indeed would seem to be borne out by the behavior of the alkali metals toward ammonia. If we are permitted to assume that the speed of the reaction between water and metallic potassium on the one hand and between potassium and ammonia on the

1 Frenzel: Ztschr. Elektrochem., 6, 480 (1900) and Ztschr, anorg. Chem, 32, 327 (1902); Moissan : Compt. Rend.. 133,7工3 (190I); Walden und Centnerzwer: Ztschr. phys. Chem., 39, 52: (1902) and Ztschr. anorg. Chem., 30, 155 (1902); Dammer: Handb. anorg. Chem., 4, 295 (1903): Goldschmidt ; $Z$ tschr. anorg. Chem., 28, Irg (1gor); Spiegel: "Der Stickstoff und seine wichtigsten Verbindungen," p. 394 (Ig03).

2 Loc. cit., p. 285. 
other is in any way dependent upon the concentration of the hydrogen ions in the respective solvents, then, in view of the fact of the slowness of the action between ammonia and potassium it is necessary to conclude that the value above given for the specific conductivity of liquid ammonia is much above that of the really pure solvent. It is further to be remembered in making this comparison, that when potassium reacts with water the action takes place only at the surface of contact between the metal and water, while in ammonia, the metal, being in solution. is in a much more favorable state for reacting with the liquid.

\section{CONSTANTS AND UNITS.}

During the course of the present investigation six different conductivity cells were used each with its own cell constant. Since the results given below are not such as would be used for precise calculations it seems allowable to omit the details of the calibrations of these cells for the sake of brevity, and to give only the final results as calculated from our data. The units proposed by Kohlrausch ${ }^{1}$ are used in this as in our previous paper. In the tables $\psi$ Io $^{-3}$ denotes the dilution in liters per mol and $\Lambda$ denotes the molecular conductivity at the corresponding dilutions. All the measurements were carried out at the boiling-point of liquid ammonia, $-33^{\circ}$. Contrary to the procedure in our earlier paper, no corrections have been made in this paper for the conductivity of the solvent.

Numerical Results.

\begin{tabular}{cccc}
\multicolumn{4}{c}{ TABIE XXVI.-FORMAMIDE. } \\
$\psi / 1000$. & 1. & $\psi / 1000$. & 1. \\
1.70 & 1.08 & 26.4 & 1.87 \\
3.40 & 1.20 & 52.2 & 2.13 \\
6.76 & 1.39 & 103. & 2.37 \\
13.3 & 1.63 & 203. & 2.58
\end{tabular}

TABLE XXVII.-ChLORACETAMIDE.

I 3.9

0.42

After one hour $\Lambda$ had increased to I.7.

TABIE XXVIII.-CYANACETAMIDE.

$\begin{array}{rrrr}1.32 & 2.15 & 40.9 & 3.75 \\ 2.68 & 2.02 & 81.0 & 4.97 \\ 5.30 & 2.16 & 160.0 & 6.79 \\ 10.4 & 2.72 & 316.0 & 9.3 \mathrm{I} \\ 20.7 & 2.83 & & \end{array}$

1 Kohlrausch, Holbozn and Diesselhorst: Wied. Ann, 64, 4I7 (I898) and Kohlrausch und Halborn : "Leitvermogen der Elektrolyte," p. 3. 
ELECTRICAL CONDUCTIVITY OF AMMONIA SOLUTIONS. I95

TABLE XXIX.-CyanaCeTAMIDE.

$\begin{array}{rccc}\psi / 1000 . & \Lambda . & \psi / 1000 . & \Lambda . \\ \text { I.I I } & 2.28 & 67.4 \mathrm{I} & 4.99 \\ 2.24 & 2.09 & 133.2 & 6.74 \\ 4.42 & 2.10 & 263.3 & 9.19 \\ 8.73 & 2.38 & 520.0 & 12.62 \\ \text { I7.25 } & 2.9 \mathrm{I} & 1029.0 & 17.37 \\ 34.1 \mathrm{I} & 3.90 & & \end{array}$

TABIE XXX.-PHENYLACETAMIDE.

5.40

10.87

21.49

10.32

20.78

0.318

42.48

0.443

0.360

83.95

0.487

TABLE XXXI.-BENZAMIDE.

1.675
3.372
6.662
13.17
26.03
51.44
101.7
$0.28 \mathrm{I}$

41.07

0.364

TABLE XXXII.-THIOBENZAMIDE.

6.66
13.40
26.49
52.35
103.5
204.5
404.2

2.952
3.613
4.505
5.757
7.525
9.998
13.44

201.0

397.2

$785 . \mathrm{I}$

1552.0

3067.0

6062.0

11980.0

I8. I I

$24.5 \mathrm{I}$

33.15

44.69

59.95

79.34

105.7

TABIE XXXIII. - PhTHALIMIDE.

$\begin{array}{rrr}40.27 & 799.0 & \text { I } 44.8 \\ 45.77 & \text { I579.0 } & \text { I } 70.1 \\ 54.01 & 3121.0 & 193.8 \\ 65.30 & 6169.0 & 213.6 \\ 80.11 & \text { I2190.0 } & 229.8 \\ 98.36 & 24100.0 & 242.9 \\ \text { I20.0 } & 47630.0 & 254.4 \\ \text { TABLE XXXIV. -CYANAMIDE. } & \\ 5.02 & 94.4 & 12.16 \\ 6.40 & 211.0 & 17.27 \\ 8.69 & & \end{array}$

TABLE XXXV.-CYANAMIDE.

8.03

10.5

20.7

8.32

18.9

42.2

$\begin{array}{rrr}5.24 & 41.0 & 9.13 \\ 5.63 & 81.0 & \text { I2.13 } \\ 7.01 & & \end{array}$

TABLE XXXVI.-SULPHAMIDE.

3 I. 3

$3 \mathrm{I} .9$

46.4

64.8

25.0

132,0

25.8

I 91.0

267.0

38.2

28.0

388.0

40.6

30.2

33.0

43.2

93.9 


41000.
65.97

6.34
12.76
25.22
49.85
98.54
194.8

12.02

24.19

$47.8 \mathrm{r}$

94.50

I68.8

$$
2.83
$$

1

I 4.02

28.22

5.77

I 10.2

217.9

430.6

$$
5.03
$$$$
10.12
$$$$
20.01
$$

39.55

78.15

I 58 . I

305.3

10.89
21.91
48.30
85.59
169.2
334.4

39.4
78.3
155.1
307.2
610.9

TABLE XXXVII. -NitraMIDE AT - $70^{\circ}$.

$\begin{array}{ccc}1 . & \psi_{1000} & \Lambda . \\ 50.95 & 97.66 & 56.55\end{array}$

TABLE XXXVIII.-METHYLNITRAMINE.

$\begin{array}{rrr}39.39 & 385.0 & 120.3 \\ 44.79 & 760.9 & 145.2 \\ 52.87 & 1504.0 & 171.6 \\ 64.25 & 1972.0 & 196.2 \\ 79.1 S & 5875.0 & 218.4 \\ 98.06 & \text { II } 10.0 & 235.2\end{array}$

TABLE XXXIX.—NITROGLANIDINE.

$\begin{array}{crr}4.587 & 369.2 & 19.29 \\ 5.63 \mathrm{I} & 729.6 & 23.88 \\ 7.23 \mathrm{I} & \mathrm{I} 442.0 & 32.5 \mathrm{I} \\ 9.565 & 2850.0 & 44.16 \\ \text { I } 2.86 & & \\ \text { TABLE XL._URETHANE. } & \end{array}$

TABLE XLI.-NITROURETHANE AMMONIUM.

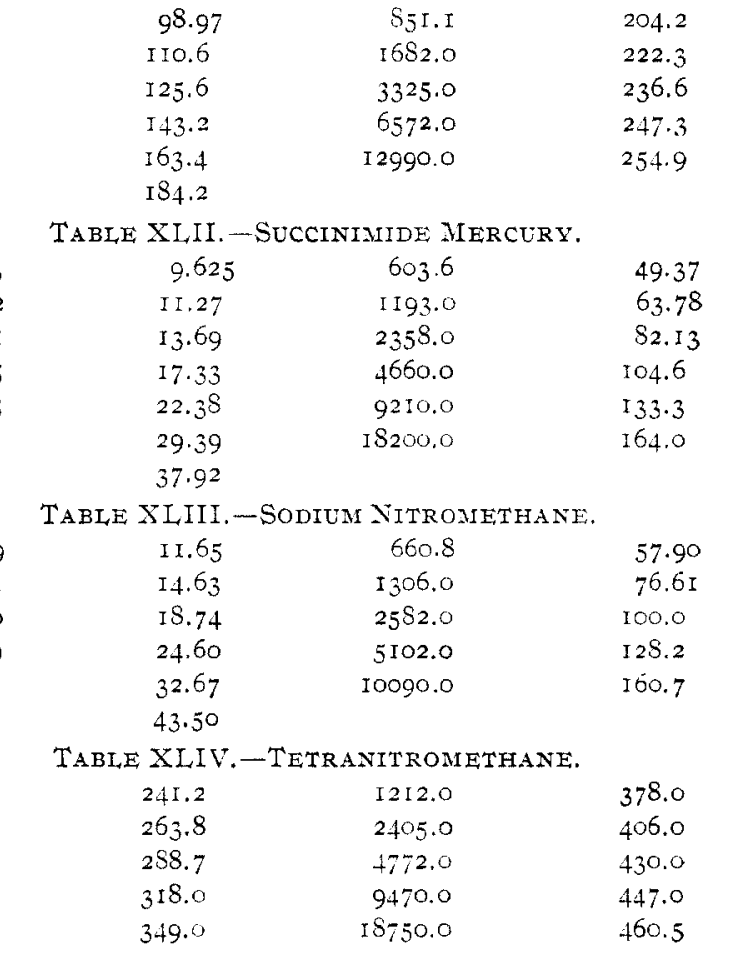


TABLE XLV.-TRINITROBENZENE.

$\psi / 1000$.

52.35

I03. 5

204.5

404.2

798.9

II. IO

I7. 10

22.34

27.76

42.00

54.88

68.20

103.1

51.55

73.27

I. 16

I. 78

2.32

2.89

3.37

$5.7 \mathrm{I}$

4.48

9.02

17.85

35.25

69.69

I. 43

2.88

4. I 2

8.29

I 6.40

32.40

185.3

274.0

393.2

556.8

780.5

A.

I 26.6

I 42.5

I 59.3

I 74.7

I9I.O

TABLE XLVI.-TRINITRANILINE.

$\begin{array}{lrr}\text { IO9.5 } & 54.58 & \text { I } 41.0 \\ \text { I20.0 } & \text { IO9.7 } & \text { I55.2 } \\ \text { I } 25.4 & 216.7 & \text { I69.8 } \\ \text { I } 29.7 & 428.3 & \text { I } 84.2 \\ I 37.8 & 846.6 & \text { I98.6 } \\ I 42.3 & I 673.0 & 209.5 \\ \text { I } 47.3 & 3307.0 & 2 I 9 . I \\ I 55.7 & 6537.0 & 226.4\end{array}$

TABLE XLVII.-POTASSIUM CYANIDE.

$$
\begin{aligned}
& \text { I } 0.2 \\
& \text { I I } 6.2
\end{aligned}
$$$$
\text { IO2.7 }
$$

I 29.2

TABLE XLVIII.-MERCURY CYANIDE.

$\begin{array}{lcc}2.48 & 7.10 & \text { I.69 } \\ 2.37 & 10.7 & 1.66 \\ 2.22 & 17.4 & 1.65 \\ 2.26 ? & 21.8 & 1.63 \\ 1.86 & 33.0 & 1.64 \\ 1.79 & 55.6 & 1.75\end{array}$

TABLE XLIX. - SIIVER CYANIDE.

$\begin{array}{lrr}\text { I5.58 } & \text { I } 37.7 & \text { I2.4I } \\ \text { I5.39 } & 272.8 & \text { I2.12 } \\ \text { I4.28 } & 538.0 & \text { I2.00 } \\ \text { I3.45 } & \text { I063.0 } & \text { I2.00 } \\ \text { I } 2.83 & & \end{array}$

TABIE I.-ZINC CYANIDE.

$\begin{array}{lcr}\text { I6.35 } & 64.0 \text { I } & 9.86 \\ \text { I5.30 } & \text { I } 26.6 & 9.89 \\ \text { I3.85 } & 250.2 & \text { I0.36 } \\ \text { I 2.42 } & 494.4 & \text { I I.2 I } \\ \text { I0.80 } & 977.0 & \text { I 2.64 } \\ \text { IO. I4 } & & \end{array}$

TABI,E LI.-AUROUS CYANIDE.

$\begin{array}{lll}\text { I5.34 } & \text { II32.0 } & \text { I6.67 } \\ \text { I5.69 } & \text { I585.0 } & \text { I6.93 } \\ \text { I5.98 } & 2297.0 & \text { I7.24 } \\ \text { I6. } 25 & 3220.0 & \text { I } 7.57 \\ \text { I6.47 } & & \end{array}$


C. FRANKLIN AND CHARLES A. KRAUS.

TABLE LII. - LITHIUM NITRATE.

$\psi / 1000$.
25.88
$53.3 I$
109.8
218.0
432.8

25.86
51.30
105.7
209.8
416.3
826.0
1639.0
3378.0

I. 198

2.721

6.076

I 3.57

30.30

22.9

47.2

62.0

I22.9

167.6

$257 \cdot 3$

510.7

roI 3.0

1053.0

1352.0

648.7

884.5

1211.0

1755.0

2393.0

3293.0

4749.0

6476.0
$\Lambda$.

I 8.0

135.3

$155 \cdot 5$

172.3

199.2

TABLE LIII.-LithIUM NITRatz. $\psi_{i 1000}^{i}$.

858.4

1703.0

3380.0

6965.0

6960.0

13810.0

I 9030.0

28460.0

37370.0

51490.0

74150.0

Ior 100.0
A.

220.5

236.5

253.9

265.7

TABLE LIV.-Sodium Nitrate.

$\begin{array}{ccc}82.13 & 67.60 & 142.4 \\ 91.50 & 147.6 & 168.0 \\ 97.27 & 329.7 & 196.7 \\ 106.6 & 730.2 & 227.4 \\ 121.4 & 1644.0 & 252.6\end{array}$

TABLE LV.-SodIUM NITRATE.

$\begin{array}{lrr}\text { II } 6.2 & 231.0 & \text { I } 82 . \text { I } \\ \text { I32.4 } & 332.6 & \text { I95.0 } \\ \text { I39.0 } & 455.3 & 206.7 \\ \text { 2I } 4.0(?) & 900.0 & 231.0 \\ \text { I71.2 } & \text { I227.0 } & 239.5\end{array}$

TABLE LVI, - SODIUM NITRATE.

$\begin{array}{rrr}188.2 & 2857.0 & 265.5 \\ 213.9 & 3739.0 & 272.8 \\ 236.1 & 5150.0 & 278.7 \\ 237.0 & \text { IOI } 20.0 & 291.5 \\ 246.0 & & \end{array}$

TABLE LVII.-Sodium Nitrate.

$\begin{array}{rrr}220.0 & 8920.0 & 287.7 \\ 233.0 & \text { I } 2850.0 & 292.9 \\ 243.0 & \text { I } 7520.0 & 295.4 \\ 259.4 & 24150.0 & 297.7 \\ 263.0 & 34730.0 & 301.3 \\ 270.3 & 47410.0 & 303.6 \\ 277.7 & 64650.0 & 303.8 \\ 283.7 & & \end{array}$


ELECTRICAL CONDUCTIVITY OF AMMONIA SOLUTIONS. I99

TABLE LVIII.-SODIUM ChLORIDE.

$\psi / 1000$
66.3
130.2
258.5
510.2
1008.0

$\begin{array}{ccc}\Lambda . & \psi / 1000 . & \Lambda . \\ \text { I2I.8 } & 1990.0 & 247.2 \\ \text { I } 43.1 & 3930.0 & 268.8 \\ \text { I } 70.2 & 7760.0 & 285.9 \\ \text { I96.5 } & 15320.0 & 296.0 \\ 223.0 & 30330.0 & 307.0\end{array}$

TABLE LIX.-SODIUM BROMIDE.

$\begin{array}{rrrr}3.97 & 92.8 & \text { IOO.2 } & \text { I57.I } \\ 9.01 & \text { IO2.7 } & 224.0 & \text { I83.8 } \\ 20.12 & \text { II6.3 } & 500.2 & 21 \text { I.7 } \\ 44.93 & \text { I34.3 } & \text { III7.0 } & 239.1 \\ & \text { TABLE LX.-SODIUM IODIDE. } & \\ 26.45 & \text { I46.0 } & 2 \text { I4.6 } & 202.5 \\ 54.15 & \text { I64.7 } & 442.6 & 224.5 \\ \text { IO8.1 } & \text { I84.0 } & 877 . \text { I } & 245.0 \\ & \text { TABLE LXI.-SODIUM IODIDE. } & \\ 271.9 & 2 \text { IO.0 } & 42 \text { I5.0 } & 280.0 \\ 527.1 & 229.5 & 8365.0 & 290.0 \\ \text { O78.0 } & 247.8 & \text { I6600.0 } & 296.2 \\ \text { I25.0 } & 296.8 & & \end{array}$

TABLE LXII.--POTASSIUM NITRATE.

3. 13

7.10

77.6
86.5
92.9
108.0

176.5

160.9

15.85

35.40

79.05

132.0

I 95.6

231.7

265.6

TABLE LXIII.--AMMONIUM CHLORIDE.

9.84

19.80

68.75

79.05

394.2

880.2

I 966.0

39. I 4

$77 \cdot 3^{6}$

93.13

I 2.0

I 3 I. 7

$\mathrm{x} 63.3$

194.3

TABLE IXIV.-AMMONIUM BROMIDE.

$\begin{array}{rrrr}21.47 & \text { II } 6.0 & 709.0 & 224.9 \\ 44.04 & \text { I } 33.0 & 1407.0 & 251.0 \\ 87.40 & 152.5 & 2792.0 & 270.3 \\ 173.4 & 174.9 & 3846.0 & 276.1 \\ 344.0 & 199.8 & 5751.0 & 284.5\end{array}$

TABLE LXV.-AMMONIUM IODIDE.

$\begin{array}{llll}53.12 & \text { I70.8 } & \text { IO4.3 } & 193.7\end{array}$

TABIE LXVI.-ETHYLAMINE HYDROCHLORIDE.

$\begin{array}{rrrr}7.752 & 64.00 & 240.8 & 152.6 \\ 15.60 & 73.96 & 479.3 & 184.2 \\ 30.83 & 86.5 & 953.9 & 217.2 \\ 60.94 & 104.3 & 1855.0 & 248.8 \\ 121.3 & 126.0 & 3726.0 & 276.6\end{array}$




\begin{tabular}{|c|c|c|c|}
\hline$\psi_{i 1}$ & $\Lambda$ & $\psi$ & $\Lambda$ \\
\hline 6.269 & $6 I .35$ & I92.6 & 143.2 \\
\hline 12.62 & 69.95 & 380.6 & I $7 \mathrm{I} .1$ \\
\hline 24.93 & $8 I .56$ & 752.1 & 202.7 \\
\hline 49.28 & I $4.8(?)$ & $\mathrm{I}_{4} \mathrm{~S}_{5} . \mathrm{O}$ & 233.I \\
\hline $97.4 \mathrm{I}$ & I I 8.2 & 2939.0 & 261.6 \\
\hline \multicolumn{4}{|c|}{ TABLE LXVIII.-THAILIUM NITRATE. } \\
\hline 97.85 & I 55.0 & 2068.0 & 274.0 \\
\hline I94.I & I80.1 & 4104.0 & $293 \cdot 4$ \\
\hline 385.2 & $207 \cdot 3$ & 8144.0 & 306.6 \\
\hline IO 42.0 & 248.6 & & \\
\hline \multicolumn{4}{|c|}{ TABLE, LXIX. - SILIER NiTRATE. } \\
\hline 68.95 & 148.7 & 2892.0 & $259 \cdot 5$ \\
\hline I36.8 & I 62.5 & 5740.0 & 271.0 \\
\hline I 86.6 & $18 \mathrm{I} .7$ & I I 380.0 & 278.9 \\
\hline $370 . \mathrm{I}$ & 204.8 & I 5690.0 & $282 . I$ \\
\hline 734.5 & 226.4 & 22600.0 & 285.5 \\
\hline I 458.0 & $245 \cdot 0$ & $30 \$ 00.0$ & 287.2 \\
\hline \multicolumn{4}{|c|}{ TABLE LXX. -SIIVER IODIDE. } \\
\hline 62.4 & 42.52 & 967.2 & $12 \mathrm{I} . \mathrm{O}$ \\
\hline $\mathrm{I} 23.8$ & 56.20 & 2617.0 & 165.7 \\
\hline 245.7 & 73.63 & 5192.0 & 197.0 \\
\hline 487.4 & 94.92 & 10310.0 & 226.7 \\
\hline \multicolumn{4}{|c|}{ TABLE LXXI.-BARIUN NITRATE. } \\
\hline 9I.I & IOI.3 & 3805.0 & 245.5 \\
\hline 125.5 & 110.8 & $754^{2.0}$ & 280.0 \\
\hline I80.6 & $\mathrm{I} 2 \mathrm{I} .9$ & 14950.0 & 319.4 \\
\hline $3.5^{8.0}$ & $\mathrm{I} 47.2$ & 29647.0 & 366.9 \\
\hline 709.9 & $I 72.6$ & $5^{8750.0}$ & 422.5 \\
\hline 1407.0 & 200.6 & I I 6500,0 & 498.5 \\
\hline \multicolumn{4}{|c|}{ TABLE LXXII.--WATER. } \\
\hline $\begin{array}{r}0.574 \\
\text { I. } 184\end{array}$ & $\begin{array}{l}0.0052 \\
0.0060\end{array}$ & I. 454 & 0.0063 \\
\hline
\end{tabular}

The tabulated results are plotted in the following plates in which the ordinates represent the molecular conductivities and the abscissae the logarithms of the dilutions. The logarithms of the dilutions are chosen for the reason that their use gives a better distribution of points for the more concentrated solutions than either the cube roots of the dilutions or the dilutions themselves. Since, however, the transformation is unsymmetrical the method suffers the disadvantage of giving curves which are dis- 
torted in such a manner that those portions of the curves representing the more concentrated solutions are concave towards the axis of ordinates when as a matter of fact they should be concave towards the axis of abscissae.

In Plate I are plotted curves for the acid amides and the nitrocompounds. The curve for potassium nitrate is included in

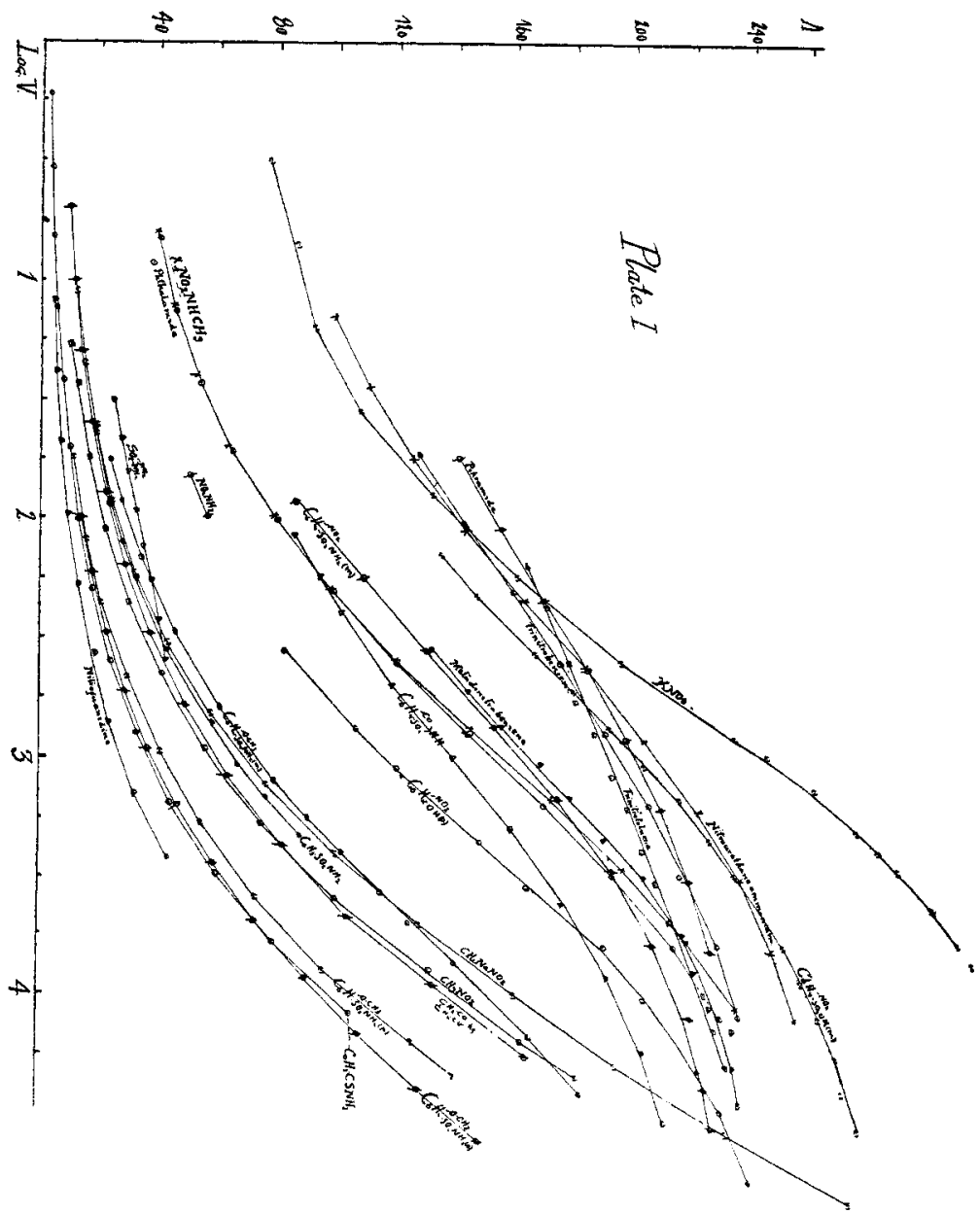

order that ready comparison may be made between these solutes and the behavior of the uni-univalent salts.

In Plate II are given the curves for the cyanides. The curve 
mercury cyanide $\mathrm{B}$ is drawn to a different ordinate scale in order to bring out more clearly the similarity of the behavior of this salt to that of the other cyanides. Three poor conducting acid amides are included in this plate.

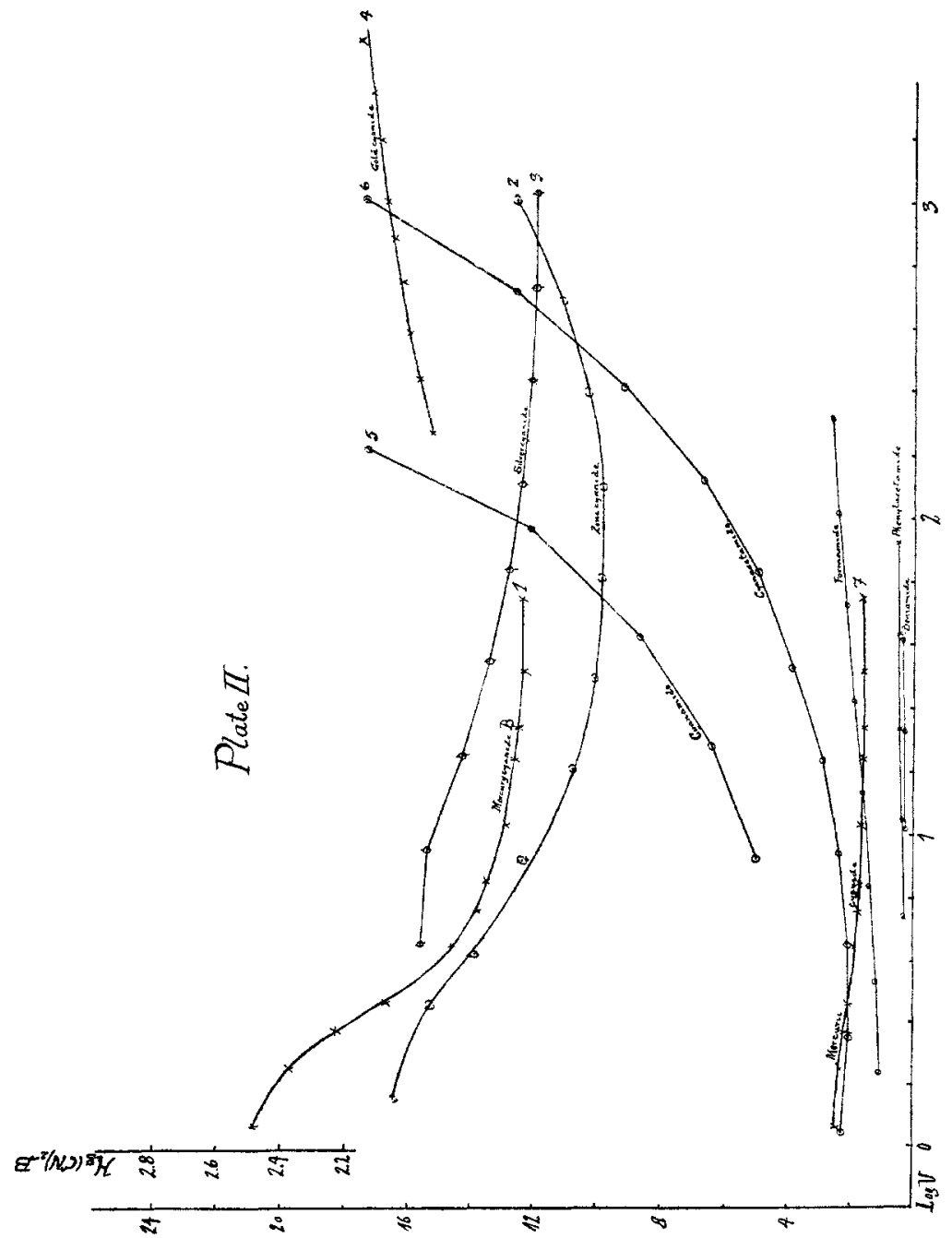

The curves for the uni-univalent salts are given in Plate III. There is also here included curves showing the conductivity of certain salts in water solution at $18^{\circ} .1$ These curves show the

1 Data are from Kohlrausch and Holborn : "Leitvermögen der Elektrolyte, p. rjg. 
interesting fact that the molecular conductivity of salts in ammonia, although very much higher in dilute solutions, is considerably lower in the more concentrated solutions than in water solu-

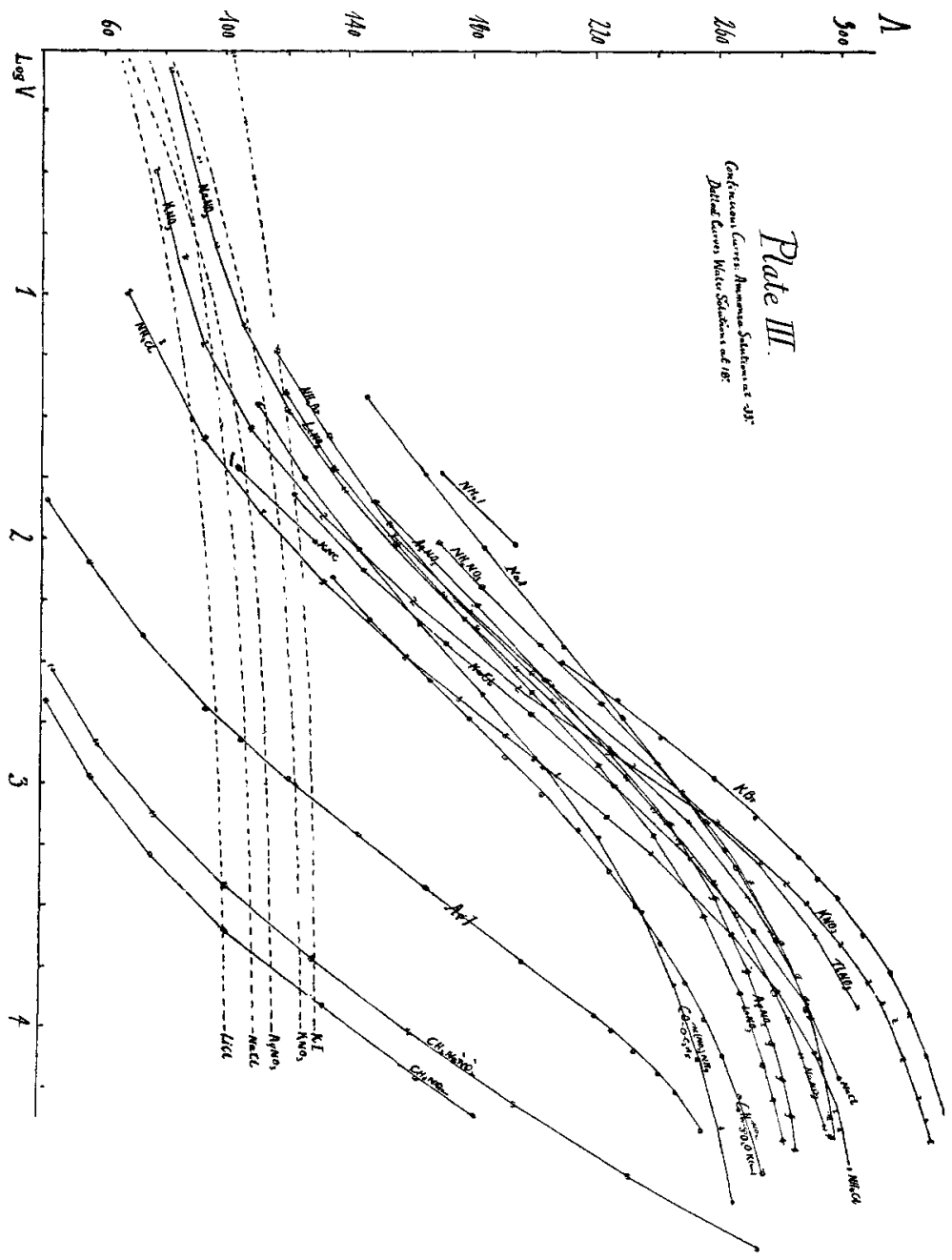

tions of the same concentration. This is, to be sure, a result that was to be expected in view of the low dissociating power of ammonia as a solvent and notwithstanding the much greater mobility of the ions in the latter solvent. ${ }^{1}$

1 Franklin and Cady: This Journal, 26, 499 (I904). 
Plate IV shows the effect of dilution on the dissociation of uniunivalent salts in water at $18^{\circ}$ and in ammonia at $-33^{\circ}$.

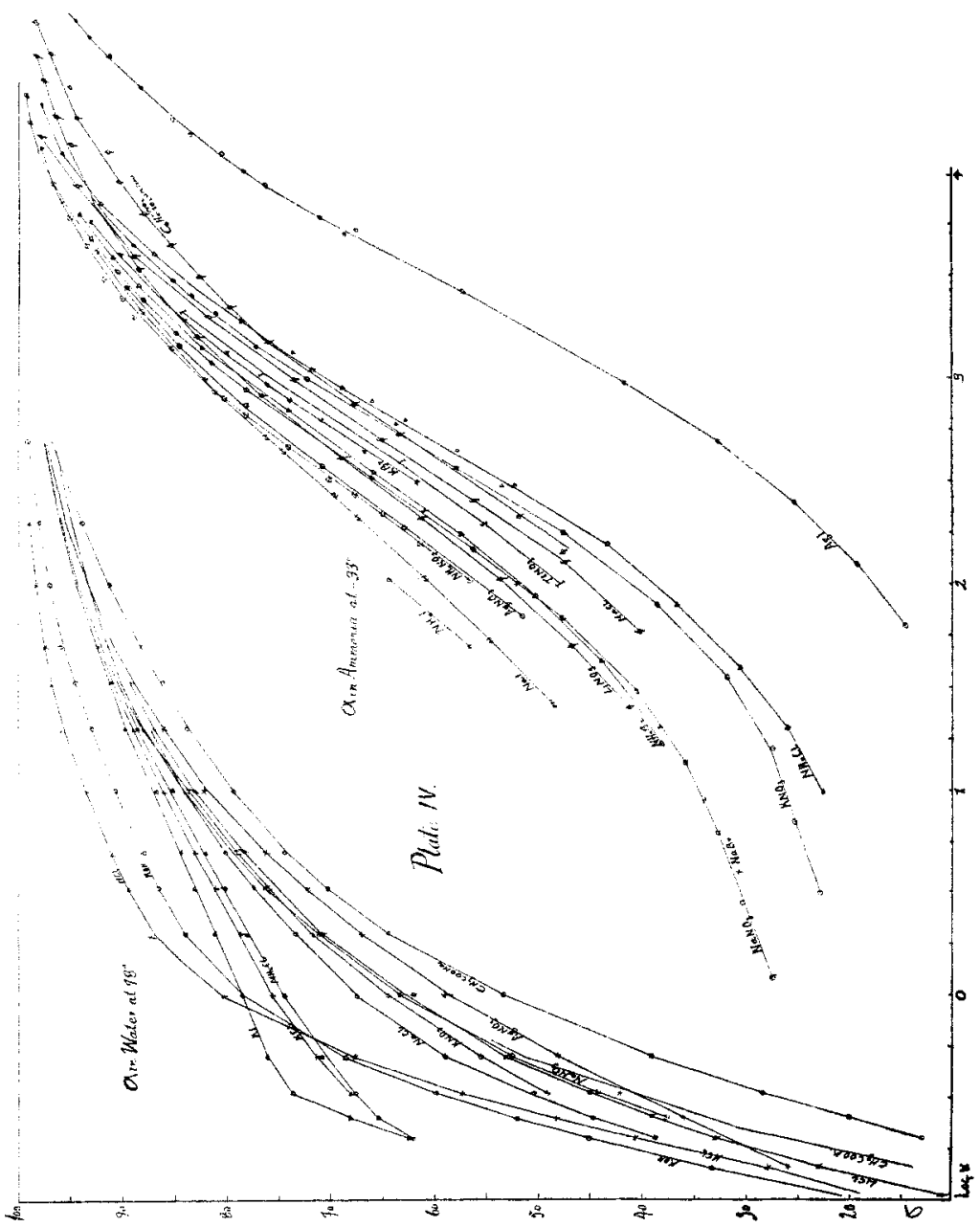

Nort. - The following addenda are to be made to the plates given in our earlier paper-Am. Chem. J., 23 (1900):

On page 309.-I-Metadinitrobenzene, 2-orthonitrophenol, 3-metamethoxybenzenesulphonamide, 4-benzenesulphonamide, 5-nitromethane, 6-paramethoxybenzenesulphonamide, 7-orthomethoxybenzenesulphonamide, 8-trinitrotoluene. 
On page 310.-r-Potassium bromide, 2-potassium nitrate, 3-ammonium chloride, 4-ammonium nitrate, 5-silver iodide, 6-strontium nitrate.

On page 31 r.-I-Sodium bromide, 2-potassium metanitrobenzenesulphonate, 3-sodium bromate, 4-metanitrobenzenesulphonamide, 5-benzoic sulphinide.

\section{DISCUSSION OF RESULTS.}

Acid Amides.-(Tables I5-2 I inclusive and 26-4I inclusive and Plates $I$ and $I I)$. The analogy between the acid amides and ammonia on the one hand and the oxygen acids and water on the other has been shown to extend to the behavior of the solutions of the acid amides in ammonia. ${ }^{1}$ The acid amides generally are easily soluble in ammonia, and in this solvent they enter into metathetic reactions with the metallic amides in a manner entirely analogous to the reactions between acids and bases in aqueous solutions. Moreover, as is shown in the following table, the acid amides form solutions in ammonia which exhibit the same wide diversity in their power to carry the electric current as do aqueous solutions of the oxygen acids.

TABLE SHowiNg THE EIECTRICAL CONDUCTIVITy OF ACID AMIDES IN Solvtion in Liquid AmMonia.

The values for the molecular conductivities given under $\psi_{11000}=8,64$ and 8,000 , respectively, are interpolated from data contained either in the tables above or in our earlier paper.

\begin{tabular}{|c|c|c|c|}
\hline$\psi / 1000$ & 8 & 64 & 8000 \\
\hline 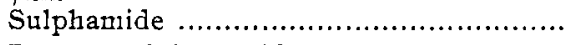 & ....... & 30.0 & ........ \\
\hline Benzenesulphonamide......................... & ...... & $2 \mathrm{I} .0$ & I 30.0 \\
\hline Orthomethoxybenzenesulphonamide ........ & ...... & 10.0 & 89.0 \\
\hline Metamethoxybenzenesulphonamide.......... & ....... & 25.0 & 154.0 \\
\hline Paramethoxybenzenesulphonamide.......... & ...... & 14.0 & 109.0 \\
\hline Metanitrobenzenesulphonamide............. & ...... & 82.0 & 232.0 \\
\hline Nitramide at $-80^{\circ}, \ldots \ldots \ldots \ldots \ldots \ldots \ldots \ldots \ldots \ldots \ldots \ldots \ldots \ldots \ldots \ldots \ldots$ & $\ldots \ldots$ & 51.0 & $\ldots \ldots$ \\
\hline 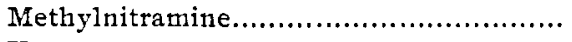 & 31.0 & 70.0 & 226.0 \\
\hline 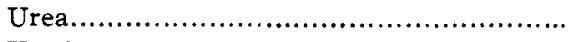 & \multicolumn{3}{|c|}{ Very poor conductor } \\
\hline 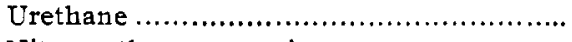 & 0.0 .3 & ...... & ........ \\
\hline Nitrourethaneammonia.......................... & 90.0 & I30.0 & 250.0 \\
\hline Nitroguanidine................................... & 4.5 & 8.0 & $70.0^{2}$ \\
\hline 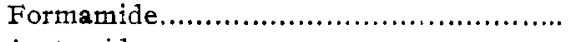 & I. 35 & 2.19 & 2.54 \\
\hline 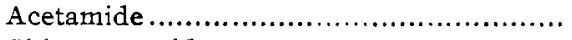 & 0.30 & 0.53 & $\ldots \ldots$. \\
\hline Chloracetamide ................................. & $0.40^{2}$ & ...... & ....... \\
\hline 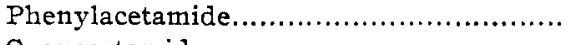 & 0.34 & 0.45 & $\cdots \cdots$ \\
\hline 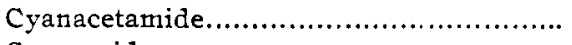 & 2. 17 & 4.25 & 7.90 \\
\hline 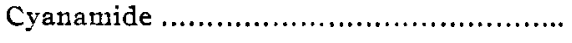 & 5.24 & 10.6 & ....... \\
\hline
\end{tabular}




\begin{tabular}{|c|c|c|c|}
\hline$\psi / 1000$ & 3 & $6_{4}$ & 8000 \\
\hline Benzamide............ & 0.27 & 0.40 & …... \\
\hline Thiobenzamide ............... & 4.9 & I0. 8 & 87.0 \\
\hline Phthalimide ....................................... & 41.0 & 70.0 & 220.0 \\
\hline 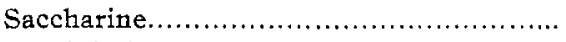 & ....... & 75.0 & 190.0 \\
\hline 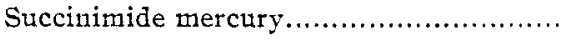 & 10.6 & 26.7 & I 26.0 \\
\hline 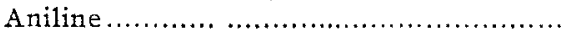 & \multirow{2}{*}{\multicolumn{3}{|c|}{$\begin{array}{l}\text { Very poor conductor } \\
\text { Fair conductor }\end{array}$}} \\
\hline 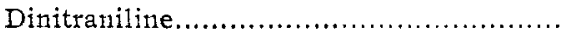 & & & \\
\hline Trinitraniline (Pikramide) $\ldots . . . \ldots \ldots \ldots \ldots$. & 100.0 & 143.0 & 229.0 \\
\hline
\end{tabular}

Obviously the amides of the weaker acids are poor conductors, some of them very poor, while the amides of the stronger acids conduct the current very well. For example, the amide of the weak carbonic acid scarcely conducts the current at all, acetamide and benzamide form poor conducting solutions, formamide solutions conduct much better, while the amides of the strong sulphonic acids, of nitric acid and of sulphuric acid form solutions which are excellent conductors.

Just as with the weak organic acids the substitution of hydrogen by a negative atom or group of atoms is accompanied by a marked increase of their conducting power in aqueous solution, so with the acid amides, this substitution is accompanied by a similar increase in the conductivity of the ammonia solution. Thus the conductivity of a solution of acetamide at a dilution of 64 litres is 0.53 , while at the same dilution the conductivity of a solution of cyanacetamide is 4.2 ; at a dilution of 64 litres the molecular conductivity of benzenesulphonamide is $2 \mathrm{I}$.O while that of metanitrobenzenesulphonamide is 82.0. Still more striking examples of this relation are found in a comparison of urethane and benzamide with nitrourethane and thiobenzamide respectively. Urethane has scarcely more than a measurable conductivity while nitrourethane ammonia exhibits the high conductivity of the binary salts. The table also shows that parallel to the behavior of phenol and its nitro derivatives in water is the behavior of the nitranilines in ammonia. As is picric acid in water so is pikramide in ammonia an excellent conductor of electricity.

It must be noted in this connection, however, that contrary to what might perhaps be expected, chloracetamide is not a better conductor than acetamide nor do the amides of the stronger benzoic and phenylacetic acids exceed acetamide in their conducting power. Furthermore, the acid amides are uniformly 
much poorer conductors in ammonia than are the corresponding acids in water, as evident from a

TABLE Showing the CONDUCtivity OF ACIDS IN Wathr as Compared WITH THE CONDUCTIVITY OF THE CORRESPONDING ACID AMIDES IN AMMONIA.

Acetic acid.......................... $\quad 9.2$ In ammonia $\psi / 1000=64$

Phenylacetic acid................ $\quad$ I5.8 Acetamide........................ 0.53

Cyanacetic acid ................. I 12.3 Phenylacetamide................ 0.45

Formic acid...................... $33^{\mathrm{T} .2}$ Cyanacetamide .................. 4.25 Formamide...................... 2.18

Benzoic acid .................... 16.0

Picric acid........................ 300.0

Nitric acid ......................... 365.0

Sulphuric acid .................... 580.0

Benzamide ........................ 0.40

Pikramide......................... $\quad$ I43.0

Nitramide......................... 5 I.0

Stlphamide ..................... 30.0

Chloracetamides.-The mono- di- and trichloracetamides were prepared with a view of measuring the conductivity of their solutions but it was found that these solutions increase in conductivity very rapidly on standing, a result probably due to the formation of ammonium chloride and aminoacetamides by the action of the solvent on the acid amides. The molecular conductivity of chloracetamide, for example, gave at $\psi_{1} \mathrm{I}^{-3}=13.9 \mathrm{a}$ value for $\Lambda=0.42$ when first measured. After an hour the conductivity had increased to 2.4 .

Sulphamide (Table 36, Plate I).-According to Hantzsch and Holl $^{1}$ an aqueous solution of sulphamide is a non-conductor of electricity. In ammonia, in which it is extremely soluble, the amide must, on the contrary, undergo considerable ionization as is shown by the measurements given above. The sulphamide used was made according to the directions given by Traube $^{2}$ and was contaminated with a small quantity of some substance insoluble in ammonia. The impurity gave to the aqueous solution an acid reaction but did not impart to the acid amide the bitter taste refered to by Hantzsch and Holl. It must be admitted that possibly the observed conductivity of the ammonia solution was due to an impurity and indeed the form of the conductivity curve suggests the higher arm of a binary salt curve. Furthermore, in the light of the close general resemblance noted by Hantzsch between carbamide and sulphamide, it is evident that new observations upon a carefully purified

\footnotetext{
1 Ber. d. chem. Ges., 34, 3436 (1901).
}

2 lbid., 26, 607 (1893). 
preparation will be necessary to settle definitely the matter of its conductivity in ammonia solution. At the same time it is difficult to believe that sufficient impurity soluble in ammonia was present to cause the high conductivity observed.

Nitramide $e^{1}$ Table 37 , Plate I). - This amide was prepared according to the directions of Thiele and Lachman." It is a very unstable substance and, according to its discoverers, is especially sensitive to the action of ammonia vapor. It was found, however, that if the amide is cooled down to $-33^{\circ}$ before being allowed to come into contact with the ammonia, it goes into solution without decomposing and forms a solution which is a good conductor of electricity. To accomplish this end the nitramide was weighed in a glass tube with a very thin-walled bulb blown on the end and was then immersed in the ammonia of the accessory cell in which the solution was to be made up. When the amide was cooled to the temperature of the ammonia, the bulb was broken and the solution transferred to the conductivity cell with as little loss of time as possible. The initial high value of the conductivity decreased rather rapidly and at the end of a few hours had reached a final low value of the order of a solution of water in ammonia. Obviously the same decomposition which goes on at a high rate of speed at room temperature also takes place in ammonia at $-33^{\circ}$, although much more slowly.

The attempt was then made to measure the conductivity of a nitramide solution at a temperature much below that of boiling ammonia in the hope that at this temperature the decomposition would be so slow as not to interfere seriously with measurements. The acid amide contained in the weighing tube described above was introduced into the ammonia of the accessory cell cooled by means of a bath of carbon dioxide and ether and, as soon as the solid was dissolved, the solution was transferred to the measuring cell, which was likewise cooled by the carbon dioxide-ether mixture. At this low temperature the conductivity of the solution remained practically constant during several hours, showing the decomposition to be very slow. Unfortunately, the fracture of the conductivity cell during the experiment prevented further

1 We take pleasure in acknowledging our indebtedness to Professor Arthur Lachman for the material for making the specimen of nitramide used in these measurements. We also thank him here for specimens of nitrourea, urethane, nitrourethaneammoniumnitroguanidine, biuret and dicyandiamide.

(Ann Chem. (Liebig), 288, 267 (1895). 
study of this solution. It is interesting to note that this substance is a much better conductor in ammonia than it is in water. ${ }^{1}$

Methylnitramine (Table 38 , Plate I).--The unstable nature of nitramide disappears when one of the hydrogen atoms is replaced by a methyl group. Since, however, one of the hydrogen atoms still remains it was expected that the "acid ester" would prove to be a good conductor of the current, as indeed it is. The conductivity of methylnitramine is somewhat above that of nitramide. It is to be remembered, though, that the conductivity of the nitramide solution was determined at $-80^{\circ}$, that is, $37^{\circ}$ below the temperature at which that of the nitramine was made. The conductivity of ammonia solutions at these temperatures increases between $I$ and 2 per cent. per degree rise temperature, consequently at $-33^{\circ}$ the conductivity of nitramide would lie near that of the nitramine solution.

Metallic Derivatives.-It was planned to measure the conductivity of a number of metallic salts of the acid amides ${ }^{2}$ but in this direction measurements have been accomplished upon but one metallic imide, viz., succinimide mercury (Table 42), which gives a good conducting solution. Potassium phthalimide was found to be insoluble.

Nitro compounds (Tables 12, 22, 23, 24, 42, 44, 45 and 46, Plate I).-The fact that the nitrohydrocarbons are generally readily soluble in ammonia forming solutions which in some cases are remarkably good conductors of electricity has previously been pointed out. ${ }^{3}$ We have now extended our measurements to several more such compounds.

It seems probable that in the case of the paraffin derivatives the conductivity is to be accounted for by the formation of compounds similar to $\mathrm{CH}_{2}=\mathrm{NOONH}_{4}$, that is, the true nitro compounds, Hantzsch's pseudo acids, become the ammonium salts of true acids when the former are dissolved in ammonia. It is, however, difficult to account for the conductivity of the aromatic nitro compounds on the assumption of a similar change and until the action of liquid ammonia on these compounds has been investigated it is probably useless to speculate on the subject.

\footnotetext{
1 Baur: Ann. Chem, (Liebig), 296, 95 (1897).

2 Franklin and Stafford: $A m$. Chem. J., 28,83 (1902).

a The authors: Ibid., 23, 301 (1900).
} 
Trinitrobenzene (Table 45). -The aromatic nitro compounds are all more or less soluble in ammonia, some of them giving solutions which possess strong and very characteristic colors. Nitrobenzene, which is very soluble, and ortho- and para- nitrotoluene, which dissolve but sparingly, give solutions which are but slightly colored and which do not conduct the current. The three dinitrobenzenes, I,2,4-dinitrotoluene, trinitrobenzene and trinitrotoluene form strongly colored solutions which approximate salt solutions in the facility with which they permit the passage of the current.

Nitromethane (Tables 23 and 34, Plates I and III),-In our previous paper it was shown that nitromethane is a remarkably good conductor in ammonia solution. We now find that the sodium salt possesses almost the same conductivity. This suggests, as is the case with acids in general, that, when dissolved in ammonia, nitromethane forms the ammonium salt. It was, therefore, thought worth while to determine whether ammonia nitromethane compounds could be isolated at lower temperatures.

When nitromethane is introduced into liquid ammonia at $-33^{\circ}$ the two substances unite to form a crystalline colorless mass which melts somewhere between $0^{\circ}$ and $10^{\circ}$ and is then miscible with ammonia in all proportions. A weighed quantity of nitromethane was introduced into a tube and, after weighing, ammonia was distilled into the tube until a large excess was present. Leaving the tube and contents in the ammonia bath, connection was made with a mechanical pump and the pressure was reduced until it became constant at about ${ }_{15} \circ \mathrm{mm}$. The tube was then sealed and weighed.

I.4285 grams nitromethane gave 2.2516 grams of the addition product.

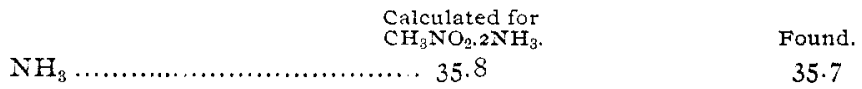

The tube was again cooled to $-33^{\circ}$ and the pressure was reduced to a few millimeters of mercury. The tube was again sealed and weighed with the following results :

I.4285 grams nitromethane gave I.8286 grams of the addition product.

$$
\begin{aligned}
& \text { Calculated for } \\
& \mathrm{CH}_{3} \mathrm{NO}_{2}, \mathrm{NH}_{3} \text {. }
\end{aligned}
$$

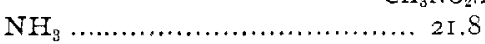

$$
\begin{aligned}
& \text { Found. } \\
& 21.9
\end{aligned}
$$


This compound has a higher melting-point than the former. On opening the tube at laboratory temperature the ammonia is all given off, leaving nitromethane behind.

It therefore appears that two ammonia addition products of nitromethane, namely, $\mathrm{CH}_{3} \mathrm{NO}_{2} \cdot 2 \mathrm{NH}_{3}$ and $\mathrm{CH}_{3} \mathrm{NO}_{2} \cdot \mathrm{NH}_{3}$ may be prepared, both of which lose their ammonia on warming up to the laboratory temperature at atmospheric pressure.

In the experiments thus described there was indication of slight decomposition of the nitromethane. This was tested further by sealing up a tube with nitromethane and ammonia. After several months' standing the liquid had assumed a dark brown color, and brown resinous appearing needles separated out at the bottom of the tube. These were not studied further.

Tetranitromethane (Table 44).-Since the presence of hydrogen is a necessary condition for the formation of salts from the nitroparaffins, it was expected that tetranitromethane, in the absence of a hydrogen atom in the molecule, would not give a conducting solution when dissolved in ammonia. Quite the contrary, however, it gives a solution possessing an exceptionally high conductivity. This behavior shows clearly that the conductivity of the solution cannot be due to the tetranitromethane as such, for the molecular conductivity reaches almost 500 units while the molecular conductivity of the best conducting binary salts does not rise above 340 units. The observed conductivity must therefore be due to the formation of new electrolytes resulting from the action of the solvent on the tetranitromethane. The following description of a short investigation of the action of ammonia on tetranitromethane gives an account of the products formed.

If a tube containing tetranitromethane is introduced into a bath of liquid ammonia, the contents solidify. On allowing ammonia gas to enter the tube the tetranitromethane absorbs it and liquefies. Some care must be exercised to prevent the absorption of an excess of ammonia at the surface before the lower layers of the solid have been acted upon, for the reason that decomposition begins in the more dilute layers. The decomposition cannot be entirely prevented, but if care is taken to stop the addition of ammonia at the point when the solid has just disappeared, the amount of decomposition will be slight. The composition of the liquid thus formed appears to be $\mathrm{C}\left(\mathrm{NO}_{2}\right)_{4} \cdot \mathrm{NH}_{3}$ as is shown by the following data. 
Weight of tetranitromethane, I.0350 grams, weight of the addition product, I. 276 grams.

$$
\begin{aligned}
& \text { Calculated for } \\
& \mathrm{C}\left(\mathrm{NO}_{8}\right)_{+}+\mathrm{NH}_{3}, \quad \text { Found. }
\end{aligned}
$$

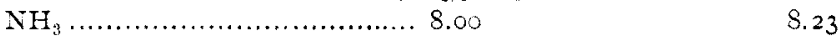

As the liquid warms up to the ordinary temperature the compound loses its ammonia and leaves tetranitromethane behind. When an excess of ammonia is introduced into the tube, the addition product does not dissolve as such, but remains in the lower portion of the tube as a distinct, denser layer which gradually enters into reaction with the supernatant ammonia, simulating in its action the behavior of a layer of phosphorus trichloride under a stratum of water. The action is accompanied by the production of much heat and the evolution of nitrogen gas. The ammonia solution at the same time assumes a strong yellow color. The gas was proved to be nitrogen by testing it with a flaming splinter, which was extinguished, by allowing it to stand over water, and by sparking it with an admixture of hydrogen gas, neither of which latter tests caused any diminution in the volume of the gas. The percentage of nitrogen evolved is not constant but varies considerably in successive experiments as is shown by the following determinations.

I. 2.0983 grams gave $125.4 \mathrm{cc}$. nitrogen at $4^{\circ}$ and $755 \mathrm{~mm}$. II. $1.616 \mathrm{I}$ grams gave III.O cc. nitrogen at $20^{\circ}$ and $760 \mathrm{~mm}$. III. 0.7515 gram gave $60.0 \mathrm{cc}$. nitrogen at $24^{\circ}$ and $740 \mathrm{~mm}$.

\begin{tabular}{cccc}
$\begin{array}{c}\text { Calculated for } \\
\text { rmolecule nitrogen. }\end{array}$ & \multicolumn{3}{c}{ Found. } \\
Nitrogen........................ 7.2 & 6.9 & 7.8 & 8.0
\end{tabular}

Some tetranitromethane was undoubtedly carried over with the gas into the receiver, for the water in the latter gradually became yellow, a result due presumably to the formation of nitroform ammonia by the action of the aqueous ammonia on the tetranitromethane.

When the action between the liquid ammonia and the tetranitromethane is complete and the tube, removed from the ammonia bath, is warmed, the excess of ammonia boils away, leaving behind a yellow, well crystallized mass which melts in the neighborhood of zero. Under reduced pressure the reaction product loses ammonia but the excess of ammonia is not all given off until, with the pressure reduced to a few millimeters, 
the temperature has been maintained at $100^{\circ}$ for some time. A small quantity of liquid, evidently water, condenses on the walls of the cooler portions of the tube. The amount has not been determined, but was estimated to be considerably less than one molecule for each molecule of the tetranitromethane used. After continued heating under diminished pressure, to remove the ammonia and water, a yellow crystalline mass remains behind in the tube. This is somewhat heavier than the tetranitromethane used as is shown by the following data.

$\begin{array}{llll} & \text { Gram. } & \text { Gram. } & \text { Gram, } \\ \text { Weight of tetranitromethane............. } & 2.8740 & 2.0983 & \text { 1.6I6I } \\ \text { Weight of reaction product............... } 2.9076 & 2.1314 & \text { I.6916 } \\ \text { Percent. increase............................ } 1.0 & \text { I.6 } & 4.7\end{array}$

If ammonia gas be introduced upon the dry reaction product, it is rapidly absorbed, the yellow mass deliquesces and goes into solution.

The dry reaction-product was removed from the tube, dissolved in alcohol and allowed to crystallize, when the deposition of crystals of two distinct forms led to the conclusion that the reaction-product must be a mixture. Addition of ether to the alcoholic solution of the yellow mass was followed by the deposition of a crop of crystals, which, after separation from the alcohol-ether solution and washing with ether, was found to consist of ammonium nitrate. The identity of the salt was proved by its behavior when heated, by the fact that it deliquesces when brought into contact with gaseous ammonia, by qualitative tests for ammonia and nitric acid, and by a quantitative determination of the ammonia contained in it. A very considerable proportion of the reaction-product was made up of this salt. The filtrate from the ammonium nitrate was concentrated until a crop of yellow, needle-like crystals was formed. The substance thus obtained is nitroform ammonia or trinitromethane ammonia. Ammonia determinations made by the usual volumetric method gave 10.5 and 10.3 per cent. $\mathrm{NH}_{3}$; calculated for $\mathrm{C}\left(\mathrm{NO}_{2}\right)_{3} \mathrm{H} . \mathrm{NH}_{3}$, ro. I per cent.

A mixture of the ammonium and potassium salts was treated with dilute sulphuric acid and the aqueous solution of the free nitroform thus obtained was extracted with ether. The yellow ethereal solution when dried over calcium chloride became entirely colorless. The ether was then removed by evaporation 
in vacuo and the acid was converted into the ammonium salt by contact with dry, gaseous ammonia. The addition product thus formed deliquesced in the ammonia gas, forming a very concentrated ammonia solution of nitroform ammonia. This liquid was mixed with warm alcohol and the solution thus formed allowed to cool, when beautiful needle-like yellow crystals of nitroform ammonia separated from the solution. The analysis gave 9.8 per cent. $\mathrm{NH}_{3}$; calculated, as above, Io. I per cent.

In further proof of the formation of trinitromethane by the action of ammonia on tetranitromethane the following experiments are described.

A portion of the product formed by the action of ammonia on tetranitromethane was dissolved in water, potassium hydroxide solution was added and the crop of yellow crystals which separated was increased by immersion of the containing vessel in ice water. The crystals were filtered off on a Witt plate, washed successively with water, alcohol and ether, and dried in vacuo.

Determinations of potassium in two separate preparations are given.

I. 0.6018 gram of the salt gave $0.275^{\mathrm{I}}$ gram potassium sulphate.

II. 0.3778 gram of the salt gave 0.1734 gram potassium sulphate.

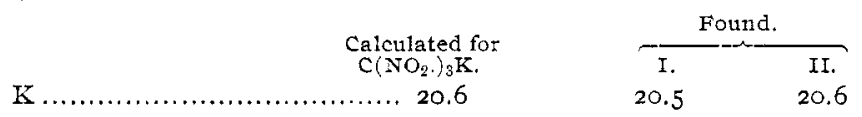

According to Hantzsch and Rinckenberger ${ }^{1}$ the salts of nitroform gradually undergo decomposition with the formation of metallic nitrate. In agreement with these observations are the following results of the analysis of three old specimens of the potassium salt.
Calculated for $\mathrm{C}\left(\mathrm{NO}_{2}\right)_{3} \cdot \mathrm{K}$.
K.

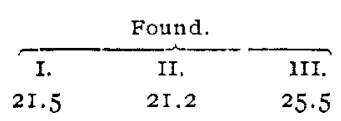

If we assume that the dry product of the action of ammonia on tetranitromethane is a mixture of nitroform ammonia and ammonium nitrate only, then the following determinations of ammonia in the mixture show the constituents to be present in the proportion of approximately 2 molecules of the former to one of the latter.

1 Ber, d. chem. Ges., 32, 631 (1899). 
Preparation I.

a. 0.2038 gram required $14.4 \mathrm{cc}$. decinormal acid.

b. 0.3865 gram required $27.5 \mathrm{cc}$. decinormal acid.

Preparation II.

a. $\quad 0.5433 \mathrm{gram}$ required $39.3 \mathrm{cc}$. decinormal acid.

b. 0.3376 gram required $24.3 \mathrm{cc}$. decinormal acid.

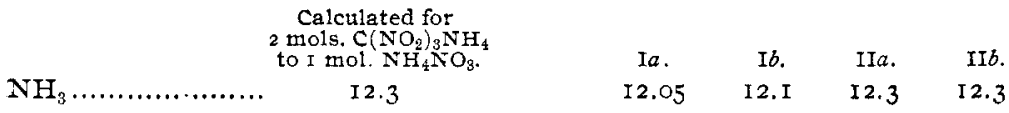

The work thus described shows that the action of ammonia on tetranitromethane results in the formation of somewhat more than 1 atom of nitrogen, something less than I molecule of water, and a mixture of nitroform ammonia and ammonium nitrate in the proportion of 2 molecules of the former to one of the latter. Furthermore, the weight of the dry mixture is slightly greater than that of the tetranitromethane used.

Agreeing fairly well with these results is either of the two equations:

I. $6 \mathrm{C}\left(\mathrm{NO}_{2}\right)_{4}+\mathrm{I}_{4} \mathrm{NH}_{3}=6 \mathrm{C}\left(\mathrm{NO}_{2}\right)_{3} \mathrm{HNH}_{3}+3 \mathrm{NH}_{4} \mathrm{NO}_{3}+3 \mathrm{H}_{2} \mathrm{O}+8 \mathrm{~N}$. II. $7 \mathrm{C}\left(\mathrm{NO}_{2}\right)_{4}+\mathrm{I} 6 \mathrm{NH}_{3}=7 \mathrm{C}\left(\mathrm{NO}_{2}\right)_{3} \mathrm{HNH}_{3}+4 \mathrm{NH}_{4} \mathrm{NO}_{3}+2 \mathrm{H}_{2} \mathrm{O}+8 \mathrm{~N}$.

It appears that the products are not the result of a coupled reaction but that several reactions are going on independently of each other. The nature of these independent reactions we have been unable to clear up with the small amount of material at our disposal.

Trinitraniline (Table 46, Plate I).--Since nitraniline, dinitraniline and trinitraniline are related to ammonia in the same way as nitrophenol, dinitrophenol and trinitrophenol are to water, it was expected that the former in ammonia would exhibit much the same gradations in conductivity that the latter do in water. Qualitative measurements showed that metanitraniline and paranitraniline possess no, or but slight, conductivity, dinitraniline is a fair conductor, while the measurements given above show that trinitraniline possesses a conductivity comparable with that of the binary salts. The nitranilines are all readily soluble in ammonia, forming strongly colored solutions. The acid nature of pikramide in ammonia solution is further shown by its behavior towards potassium amide. ${ }^{1}$

Metallic Cyanides (Tables ro, I I and 47 to $5 \mathrm{I}$, inclusive).-The measurements on potassium cyanide were not continued beyond

1 Franklin and stafiord: $A$ m. Chem. $J, 28,102$ (1902). 
the data given for the reason that the specimen of salt used did not give a clear solution, a fact due, probably, to the presence of potassium hydroxide or potassium carbonate, both of which are insoluble in ammonia. It is evident, however, from the figures given that potassium cyanide behaves normally in ammonia solution. Contrary, however, to the behavior of potassium cyanide, the cyanides of the heavy metals exhibit a unique behavior. In the first place the conductivity is low, but more striking is the fact that the molecular conductivity, instead of increasing rapidly with the dilution, at first decreases, passes through a minimum, and then increases slowly, the total change of the conductivity for a considerable range in the dilution being surprisingly small. The results of our measurements are graphically represented in Plate II. Zinc cyanide gives the most pronounced curve of any of the cyanides, but even here the change in the value of the molecular conductivity is very small in comparison with the change which other salts undergo. In the case of silver cyanide the conductivity decreases less rapidly and even at a dilution of 1,000 liters per gram-molecule the minimum has not been passed. Measurements on gold cyanide solutions have not been made on sufficiently concentrated solutions to determine whether such solutions give a minimum molecular conductivity or not. It is interesting to note that cyanacetamide exhibits much the same behavior as do the metallic cyanides and that cyanamide, although not carried to as high a concentration as was cyanacetamide, probably behaves in a similar manner, as will be seen by an inspection of the curve in Plate II.

No obvious explanation of the behavior of the cyanides presents itself. The curves have the appearance of being the resultant of two components, one being of the form of the normal conductivity curve, the other of the form of a rectangular hyperbola. The combination of these two curves would give rise to a curve which follows that of the cyanides very closely. It may be that we have to do here with a case in which a salt undergoes self-ionization. In the more concentrated solutions the self-ionization would be greatest. As the solution is diluted the dissociation due to the salt itself would decrease while that due to the solvent would increase. Finally, the conductivity due to the two factors would exchange places, the increase due to the action of the solvent becoming greater than the decrease due to the weakening of the 
self-ionization. Such action would become apparent in a substance which possessed a good conductivity in the molten state and which is not so highly dissociated by the solvent that the effect looked for would be obscured by the action of the solvent. As a matter of fact salts in water solution do not obey the dilution law and the discrepancy is in the direction above indicated. Some experiments by one of the writers, the results of which have not yet been published, indicate the possibility of such an explanation. Salts dissolved in boric anhydride conduct the current, but as the dilution is increased the molecular conductivity instead of increasing, as a matter of fact, falls, following the form of the first portion of the curves for the cyanides. The conductivity in this case does not pass through a minimum but approaches the axis of dilution asymptotically. There are, however, many difficulties in the way of such an explanation. For example, the molecular conductivity minimum for silver cyanide is not yet reached at a dilution of $I, 000$ liters per mol. At such a dilution it is difficult to believe that the salt can exercise an appreciable selfionizing action.

METALLIC SALTS.

All the measurements on uni-univalent salts given in our earlier paper were made on dilute solutions, the object in view being the determination of the maximum molecular conductivity of the salts studied. The cell was made especially for dilute solutions, and was not adapted to the measurement of low resistances. In extending this earlier work it was our purpose to select a considerable number of uni-univalent, uni-bivalent, and uni-trivalent salts-no bi-bivalent salts have been found which are soluble in ammonia-and to measure their conductivity through as large a range of concentrations as possible. We are able to record measurements on a number of salts in addition to those previously given, but of these only four have been investigated at higher concentrations and they, even, have not been carried to saturated solutions. The results obtained are given in Tables 30 to 46 inclusive, and are shown graphically, together with the earlier measurements, in Plate III. The wide variations in the conductivities of the different salts with the concentration are shown by the bewildering manner in which the curves cut each other. Conspicuous on the one hand are ammonium iodide and sodium iodide for the high conductivity 
of their more concentrated solutions, white on the other hand potassium nitrate, ammonium chloride, and especially silver iodide, are marked by low values for the molecular conductivities in the more concentrated solutions. Potassium nitrate, next to potassium bromide, shows the highest value for $\Lambda \infty$, and is unique in giving a curve which cuts nine others, thus showing that the more concentrated solutions of this salt are poorer conductors than the equivalent solutions of any one of the following named salts: thallium nitrate, sodium iodide, ammonium nitrate, sodium bromide, silver nitrate, amnonium bromide, lithium nitrate, sodium nitrate, and ammonium nitrourethane. This behavior of potassitum nitrate is followed by other salts in a less conspicuous degree as is evident from an inspection of the plate.

If the assumption be made that changes in concentration have no effect on the mobilities of the ions, ${ }^{1}$ then it is obvious that variations in conductivity must be accompanied by corresponding changes in the dissociation. Sodium iodide and ammonium iodide, for example, must be nore highly ionized in the more concentrated solutions than any other of the salts studied. The quantitative effect of dilution on the dissociation of the uniunivalent salts, together with a comparison in this respect of the behavior of water and ammonia solutions, follows in the table on page $2 \mathrm{ro}$.

This table, in the first place, brings out clearly the marked difference in the ionizing power of the two solvents. Potassium nitrate, for example, in a third-normal solution in ammonia is less than one-fourth dissociated while in water at the same concentration three-quarters of the salt in solution are in the ionic condition. At a dilution of $\mathrm{I}, 000$ liters per mol the salt is still, in ammonia solution, less than three-fourths dissociated, while in water the dissociation is practically complete. In the second place the table shows that for equal concentrations the degree of ionization varies in a marked manner from solute to solute, a fact well enough known, perhaps, of aqueous solutions but here also shown to hold true of ammonia solutions. It is worth while to call especial attention to silver iodide, which gives with ammonia a conducting solution in which the solute is dissociated to an extent surprisingly low. These relations, which are evident from the table, are shown graphically and in detail in Plate IV.

I Frauklin and Cady: This Journa1, 26, 499. 
TABle Showing the Comparative Ionizing Power of Ammonia AND WATER.

$\alpha^{1}$ in ammonia at $-33^{\circ}$.

$\psi / 1000$

$\begin{array}{llll}0.23 & 0.26 & 0.4 \mathrm{I} & 0.73\end{array}$

$\alpha$ in water at $8^{\circ}$.

0.5. 3.3 10. 100.

$\mathrm{KCl}$

…............

0.55

0.76

0.83

$0.95^{2}$

...... 0.73

$\begin{array}{ll}0.7 \mathrm{I} & 0.8 \mathrm{I}\end{array}$

0.83

$0.97^{3}$

$\mathrm{KBr}$

$$
\begin{array}{ll}
0.47 & 0.77
\end{array}
$$

0.76

$0.8 \mathrm{I}$

0.86

$0.94^{2}$

......

\subsection{9}

0.83

.......

KI.

$\mathrm{C}_{6} \mathrm{H}_{4}(\mathrm{NO}$
$\mathrm{NaNO}_{3}$.

$$
\text { ........ }
$$

(.................

......

$$
\ldots . . .
$$

0.84

$0.94^{3}$

\subsection{7}

0.83

…...

$0.95^{5}$

$0.3^{\circ}$

0.34

0.43

$0.7 \mathrm{I}$

.......

0.52

0.77

......

$0.95^{2}$

$0.53^{6}$

0.70

0.84

.......

0.59

0.77

0.79

$0.94^{2}$

$\mathrm{NaCl}$

0.30

$\begin{array}{llll}\ldots . . & 0.44 & 0.75\end{array}$

.......

0.84

$0.95^{3}$

$\mathrm{NaBr}$

$$
\text { (0.40) } 0.60
$$

0.82

NaI.

$$
\begin{array}{lll}
\ldots . . . & 0.56 & 0.85
\end{array}
$$

$0.7 \mathrm{I}$

.......

.......

$0.94^{2}$

$0.92^{5}$

0.73

$\begin{array}{lll}0.88 & 0.92\end{array}$

$0.92^{5}$

$\mathrm{NH}_{4} \mathrm{NO}_{3}$

$\mathrm{HNO}_{3}$..

......

$\mathrm{NH}_{4} \mathrm{Cl}$.

0.23

$\mathrm{HCl}$.

......

$0.65^{6}$

0.86

.......

0.68

\subsection{5}

0.82

$0.90^{8}$

$0.7 \mathrm{I}$

0.89

0.93

$0.97^{2}$

0.67

0.80

0.85

$0.94^{2}$

$\mathrm{NH}_{4} \mathrm{Br}$.

...... ..... ......

$\mathrm{NH}_{4} \mathrm{I}$.

0.52

0.78

0.64

0.53

0.78

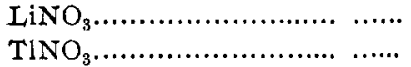

0.47

0.76

$\mathrm{AgNO}$

0.54

0.18

0.82

0.43

The authors have been able to discover but few general relations from a study of these curves; each salt seems to have a more or less specific behavior of its own. However, a comparison of the two groups of curves in Plate IV brings out clearly the marked superiority of water over ammonia as an ionizing solvent. It is also evident that in ammonia solutions the anions exert a greater influence on the dissociation than the cations, for the

1 The values for $\Lambda_{\infty}$ used in calculating a for ammonia solutions are $\mathrm{KNO}_{3}=338$ $\mathrm{KBr}=34 \mathrm{I}, \mathrm{NaNO}_{3}=298, \mathrm{NaCl}=302, \mathrm{NaBr}=302, \mathrm{NaI}-302, \mathrm{NH}_{4} \mathrm{NO}_{3}=300, \mathrm{NH}_{4} \mathrm{Cl} \mathrm{NH}_{4} \mathrm{Br}$, $\mathrm{NH}_{4} \mathrm{I}=304, \mathrm{LiNO}_{3}=290, \mathrm{TlNO}_{3}=325, \mathrm{AgNO}=290, \mathrm{AgI}=290$. The data from which the above values are obtained are found partly in our earlier paper: Loc. cit.

2 The values of $\alpha$ for the aqueous solutions are calculated from data from the following sources: Kohlrausch und Holborn: "Leitvermögen der Elektrolyte," p. I59. Measurements at $18^{\circ}$.

3 Jones atd Douglas: $A m$. Chem, $J,, 26,443$ (rgol). Measurements at $0^{\circ}$.

4 Jones and Getman : Ztschr. phys. Chem., 46, 270 (I903). Measurements at $0^{\circ}$.

5 "Leitvermögen der Elektrolyte," p. 162 . Measurements at $25^{\circ}$.

- $\Lambda_{\infty}$ taken from paper of Jones and Getman : Loc. cit.

7 Jones and Getman : Ztschr. Phys. Chem:, 49, 394 (1904). Measurements at $0^{\circ}$. 
iodides are conspicuously the most highly ionized of the salts studied. The iodides are followed in order by the bromides and chlorides. The nitrates occupy a position between the iodides and chlorides, being more highly ionized than the bromides in the case of the ammonium salts and less so in the case of the potassium salts. Sodium bromide and sodium nitrate are dissociated to practically the same extent. The effect of the cations on the dissociation is more variable and indeed the observations are too meager to allow general relations to be recognized.

In a number of cases the order of ionization changes with the dilution as is shown by the cutting of the curve for sodium nitrate by that for ammonium nitrate, of the curve for sodium nitrate and sodium bromide by ammonium bromide, of the curves for sodium nitrate, ammonium bromide, potassium bromide, thallium nitrate, potassium nitrate and ammonium chloride by those for lithium nitrate and silver nitrate, of the curves for potassium nitrate and ammonium chloride by that of potassium metanitrobenzenesulphonate, etc. In the more concentrated solutions this crossing of the curves must represent the facts. In the higher dilutions, however, the curves may wander more or less widely from their true positions as a result of the uncertainty in the determinations of the value for $\Lambda_{\infty}$ used in calculating the degree of ionization.

That a similar variability in the extent and order of ionization characterizes the behavior of uni-univalent salts in aqueous solutions is shown by the curves in Plate IV, which are plotted from data given by Kohlrausch and Holborn. ${ }^{1}$

As nearly as can be judged from the available data the order of ionization of the halogen salts is the same as in ammonia solutions, while the nitrates show a lower degree of dissociation than any of the halogen salts. A conspicuous difference in the action of the two solvents is shown by the behavior of the potassium salts. In water these are uniformly more highly ionized than the sodium salts and they also probably excel the ammonium salts in this respect. For example, the dissociation of potassium chloride, potassium nitrate, and potassium acetate is for each much higher than the corresponding sodium salt. In ammonia the potassium salts are least dissociated, that is, potassium nitrate and bromide are ionized to a less extent respectively than the corresponding salts of either sodium or ammonium. Of the two so- 
lutes potassium nitrate and sodium nitrate, the latter is more highly ionized in ammonia, while the former is ionized to the greater extent in water. Ammonium chloride is dissociated to a considerably greater extent in aqueous solution than either sodium nitrate or potassium nitrate, while in ammonia solution, with the exception of silver iodide, it undergoes less dissociation than any other salt measured. An inspection of the curves in Plate IV also shows that a similar cutting of the ionization curves is quite as characteristic of aqueous solutions as it is of solutions in ammonia. Conspicuous in this respect is silver nitrate in cutting the curves for lithium chloride and potassium acetate in concentrated solution and the curves for ammonium chloride, sodium chloride and sodium nitrate in dilute solutions, and sodium nitrate in cutting the curves for lithium chloride and potassium nitrate in one direction in the concentrated solutions and back again at higher dilutions. The curves for potassium hydroxide and hydrochloric acid cut each other, and these in turn both cut the curves for potassium iodide, potassium chloride and ammonium chloride. As is true of ammonia solutions, so also for aqueous solutions, this crossing of curves must represent the facts, at any rate in the more concentrated solutions. This comportment of the dissociation curves is, as is well known, entirely out of harmony with Ostwald's dilution law.

SUMMARY OF RESULTS.

Measurements have been made of the conductivity of thirtyseven substances in liquid ammonia solution, in addition to those recorded in our earlier paper.

The specific conductivity of liquid ammonia at its boilingpoint, $-33^{\circ}$, is below $0.01 \times 10^{-6} \mathrm{Kohlrausch}$ units. This is especially to be noted in view of the fact that a much higher value has found its way into the literature.

The acid amides are conductors of electricity in ammonia solution; some of them conduct very poorly while some substituted acid amides form solutions which carry the current with a facility equal to that of the uni-univalent salts. A table and a plate are given showing the comparative conductivities of the acid amides at different dilutions.

Many nitro-compounds, aromatic as well as paraffin, give solutions which are excellent conductors. Some of these solutions are strongly and characteristically colored. Curves showing the 
variation in the conductivities of these compounds with dilution are given in a plate along with the acid amides.

Nitromethane forms two addition products with the formulae respectively, $\mathrm{CH}_{3} \mathrm{NO}_{2} .2 \mathrm{NH}_{3}$ and $\mathrm{CH}_{3} \mathrm{NO}_{2} \cdot \mathrm{NH}_{3}$. Both compounds lose their ammonia when warmed up to laboratory temperature at the atmospheric pressure.

Tetranitromethane forms one addition product with ammonia having the formula $\mathrm{C}\left(\mathrm{NO}_{2}\right)_{4}, \mathrm{NH}_{3}$. Excess of ammonia above one molecule brings about the decomposition of the tetranitromethane and the formation of the ammonium salt of trinitromethane. This compound is very easily soluble in ammonia and forms a solution possessing an excellent conductivity.

The cyanides of the heavy metals and cyanacetamide, when dissolved in ammonia, show the remarkable phenomenon of a decrease of the molecular conductivity with the dilution in the more concentrated solutions. As the dilution increases the conductivity passes through a minimum and then increases with the dilution in the manner characteristic of salts in general.

The uni-univalent salts show a wide variation in conductivity and degree of ionization with the dilution. Tables and curves are given showing these relations and comparing the behavior of salts in solution in ammonia with their behavior in aqueous solutions.

In conclusion the authors take pleasure in acknowledging their indebtedness to Mr. Alex. Monroe for a liberal grant for carrying on this investigation and to Professor Lucien I. Blake, of the Department of Physics in the University of Kansas, for generously placing at their disposal the facilities of his department.

LELAND STANFORD, JR., UNIYERSITY AND

THE UNIVERSITY OF KANSAS.

[CONTRIBUTIONS FROM THE CHEMTCAL LABORATORY OF HARVARD COLLEGE.]

\section{A REVISION OF THE ATOMIC WEIGHT OF CADMIUM.}

Preliminary Paper.-The Analysis of Cadmium Chloride. By Gregory Patl baxter and MUrRay arnold hines.

Received Januaty 5, 1905.

IN a recent determination of the specific gravity of cadmium chloride, ${ }^{1}$ anhydrous cadmium chloride was prepared by ignition

1 Baxter and Hines: Am. Chem.J., 31, 220 (1904). 